Biol. Stud. 2014: 8(1); 29-44 • DOI: https://doi.org/10.30970/sbi.0801.340

www.http://publications.Inu.edu.ua/journals/index.php/biology

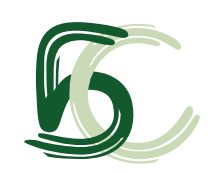

UDC: $577.113 .3,577.213 .32$

\title{
FEATURES OF THE 8-OXO-7,8-DIHYDRO-2'-dGTP BEHAVIOR IN ACTIVE SITE OF HUMAN DNA POLYMERASE $\beta$ : STRUCTURAL INVESTIGATION IN SILICO
}

\author{
A. Yu. Nyporko
}

Taras Shevchenko National University of Kyiv, 64/13, Volodymyrska St., Kyiv 01601, Ukraine e-mail:dfnalex@gmail.com; anyporko@univ.net.ua

The oxidized bases in the composition of DNA as well as DNA precursors (desoxynucleotide triphosphates, dNTPs) appearing in living cell as a result of oxidative stress are the one of major sources of genomic instability. Among oxidized forms of nitrogenous bases, the 8-oxo-7,8-dihydro-2-deoxyguanine (8odG, 8-oxo-dG) is the most ubiquitous. This compound has a high mutagenic potential due to its ability to preferably interact with adenine instead of cytosine. In particular, the 8odG in the composition of the incoming nucleotide triphosphate (8-oxo-GTP) is able to immediately incorporate into the growing DNA chain and, thus, to cause the invert replacement $d A \rightarrow d C$ because it is possible to pair with the incoming dCTP as well as dATP in the next round of DNA replication.

The efficiency of 8oxo-dG incorporation in growing DNA clearly depends on the nature of appropriate DNA polymerases. One of the most sensitive to 8-oxo-dGTP is the eukaryotic DNA polymerase $\beta$ (pol $\beta$ ). The binding of 8-oxo-dGTP in the active center of pol $\beta$ can result in two different molecular events. First of them is the incorporation of 8oxoguanine into a growing DNA chain, the other is a discrimination of 8-oxo-dGTP from the active center. While effects of incorporation of this modified guanine in DNA are well studied, the immediate consequences of 8-oxo-dGTP discrimination are still unclear.

The behavior of 8-oxo-dGTP molecule in the area of the active site of human DNA polymerase $\beta$ was investigated using molecular dynamics (MD) calculation. The principle phenomenon revealed as investigation results is existence of two cardinally different models of behavior inherent to 8-oxo-dGTP molecule. In two cases the ligand molecules loses the connections with template $\mathrm{dA}$ and starts to migrate inside of enzyme space (migrate trajectories). In the other two cases 8-oxo-dGTP stably stays in DNA polymerase active site, "keeps in touch" with template nucleotide and maintains the hydrogen bonds with it (stable trajectories).

The spatial structure of 8-oxo-dGTP in stable trajectories appears to be sufficiently rigid despite the presence of number of bonds around which the free rotation is possible, and its conformational energy is characterized by high stability over the time of studied MD. Average values of energy $(-10229.7$ and $-10227.1 \mathrm{~kJ} / \mathrm{mol})$ are practically the same for both cases. Amino acid microenvironment of 8-oxo-dGTP also practically doesn't change over the studied MD interval. Thus, stable variants of 8-oxo-dGTP behavior evidently correspond to case of the further incorporation modified 8-oxo-dG into growing DNA strand.

ISSN 1996-4536 (print) • ISSN 2311-0783 (on-line) • Біологічні Студії / Studia Biologica • 2014 • Том 8/№1 • С. 29-44 
The behavior of 8-oxo-dGTP molecule in migrate trajectories is significantly more complicated. The 8-oxo-dGTP loses the H-bonds with template dA6 (at 11 and $6.5 \mathrm{~ns}$ of MD in first and second case respectively) and starts to migrate in DNA polymerase space. The 8-oxo-dGTP spatial structure regularly exhibits much more flexibility in comparison to itself behavior in stable trajectories that reflects in corresponded values of individual atomic fluctuations. However, contrary to the expectations the general levels of conformational energy of 8-oxo-dGTP as well as energy fluctuation patterns in both migratory trajectories are completely time stable. The average values of conformational energy are -9938.6 and $-10018.6 \mathrm{~kJ} / \mathrm{mol}$ for trajectories 1 and 2 respectively that is slightly more than corresponded values for stable trajectories. The 8-oxo-dGTP movement pathways of don't coincide each other that is confirmed by differences of their conformational spaces and amino acid microenvironment. It seems to be the most important that 8-oxo-dGTP not only doesn't leave the enzyme space but directly prevent transition of DNA polymerase from closed to open conformation as well as the further binding of incoming dNTP. This observation lets a possibility to consider it as natural inhibitor of DNA pol $\beta$ activity and possible intracellular regulator which mediates the direct transition of the cell from normal state to programmed cell death omitting the malignancy stage.

Keywords: 8-oxo-7,8-dihydro-2'-dGTP, 8-oxo-dGTP, DNA polymerase $\beta$, molecular dynamics, structural analysis, delayed dissociation.

\section{INTRODUCTION}

Oxidized forms/modifications of natural nitrogenous bases appear in a living cell as a result of interaction with reactive oxygen species (ROS) $[8,22]$. The bases in the composition of DNA, as well as DNA precursors (desoxynucleotide triphosphates, dNTPs) that underwent oxidative processes, are one of the major sources of genomic instability - the additional acceptor of a hydrogen bond rearranges the normal pattern of recognition between complementary bases, which results in a missing incorporation of nucleotide in the growing DNA strand [9, 33].

Among oxidized forms of nitrogenous bases, the 8-oxo-7,8-dihydro-2-deoxyguanine (synonyms: 8odG, 8-oxo-dG, 8-oxo-deoxyguanine, 7,8-dihydro-8-oxo-2-deoxyguanine) is the most ubiquitous [31]. This compound has a high mutagenic potential due to its ability to preferably interact with adenine instead of cytosine [16]. The presence of 8odG in the template DNA strand can lead to binding of dATP opposite to it in the active center of DNA polymerase with the subsequent replacement $\mathrm{dC} \rightarrow \mathrm{dA}$ in the growing chain (strand) [2, 16, 41] (one should mention that binding of dCTP opposite to the template $80 d G$ is possible too). The 8odG in the composition of the incoming nucleotide triphosphate (80xoGTP, fig. 1 ) is able to immediately incorporate into the growing DNA chain and, thus, to cause the invert replacement $d A \rightarrow d C$ because it is possible to pair with the incoming dCTP as well as dATP in the next round of DNA replication [3]. The choice of $\mathrm{dA}$ or $\mathrm{dC}$ as preferable template for binding of the incoming 8oxoGTP strongly depends on the nature/family of DNA polymerase (DNA pols) supplying the appropriate process [24]. So, reparative DNA polymerases from $X$ and $Y$ families clearly prefer to bind 8-oxo-GTP opposite to the template dA (human pol I as well as Dhb and Dpo4 form the pair 8-oxo-GTP: dA exceptionally [37, 38]). At the same time, replicative polymerases from family B include oxidized GTP mainly opposed to the template dC [15], which is another proof of the high fidelity of this pol family $[4,26]$.

ISSN 1996-4536 (print) • ISSN 2311-0783 (on-line) • Біологічні Студії / Studia Biologica • 2014 • Том 8/№1 • C. 29-44 


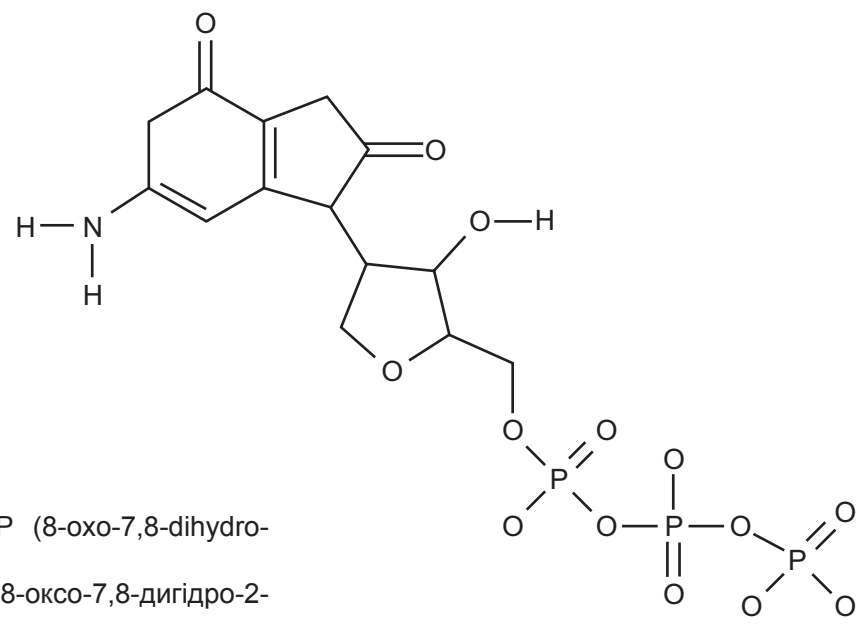

Fig. 1. Structure of the 8-oxo-dGTP (8-0xo-7,8-dihydro2-deoxyguanine triphosphate)

Рис. 1. Структура 8-оксо-дГТФ (8-оксо-7,8-дигідро-2деоксигуанін трифосфрату)

One should remark that generally the incorporation of 8oxodG in DNA is a much rare event than the incorporation of natural dG. The relative rate of 8-oxo-dG incorporation also depends on the nature of appropriate DNA polymerases. The representatives of high-fidelity $A$ and $B$ families are sufficiently resistant to the incorporation of 8-oxodGTP [24], whereas $X$ and $Y$ family pols involved in repair and/or translesion synthesis incorporate oxidized guanine in a relatively efficient manner.

The most sensitive to 8-oxo-dGTP is the eukaryotic pol $\beta$ (X family) $[6,32]$ and pol $\eta$ (Y family) $[25,37,38]$. So, human pol $\beta$ incorporates 8-oxo-dGTP with the efficiency $20 \%$ of that of a normal dNTP inclusion [32], while the effectiveness of 8-oxo-dGTP integration by human pol $\eta$ is about $60 \%$. Both pols prefer $d A$ as a template base for 8 -oxo-dGTP incorporation.

Obviously, the above-described variability of possible options of 8-oxo-dGTP interaction with complex "DNA polymerase: template DNA" is to a considerable extent caused by spatial structure features of relevant enzymes at individual and/or family level. However, one should mention that the information about spatial organization of complexes DNA polymerases with 8-oxo-dGTP is extremely limited. The human DNA polymerase $\beta$ with 8-oxo-dGTP bound at the active site is just one complex with experimentally found tertiary structure (appropriate structure data is deposited in the ProteinDataBank [5], access code 3MBY ) [1]. Nevertheless, this complex has high-quality spatial geometry in accordance with the MolProbity validation metrics $[10,13]$ and can be successfully applied as a starting point for further structural investigations.

Evidently, that binding of 8-oxo-dGTP in the active center of DNA polymerase $\beta$ can result in two different molecular events. First of them is the above-mentioned incorporation of 8oxoguanine into a growing DNA chain, the other is a discrimination of 8-oxo-dGTP from the active center. While effects of incorporation of this modified guanine in DNA are well studied and described in the literature (see [3] for a review), the (immediate) consequences of discrimination are still unclear. Based on 8-oxo-dGTP structure peculiarities, it might be supposed that behavior of 8oGTP after discrimination is essentially more complicated than a simple removing from active site. Thus, the objective of the present investigation is the structural analysis of the behavior of 8-oxo-dGTP molecule in (the area of) the active site of human DNA polymerase $\beta$ using molecular dynamics (MD) calculation.

ISSN 1996-4536 (print) • ISSN 2311-0783 (on-line) • Біологічні Студії / Studia Biologica • 2014 • Том 8/№1 • C. 29-44 


\section{MATERIALS AND METHODS}

The studied systems were prepared on the basis of the X-ray derived structure of ternary complex "human DNA polymerase $\beta$ : DNA: 8-oxo-dGTP" at 2.0 A resolution deposited in RCSB Protein Data Bank (access code is 3MBY). Molecule of 8-oxo-dGTP in pol $\beta$ active site is paired with adenine of the template strand [1]. Absent $\mathrm{N}$-terminal fragment Met1-Glu9 was recovered by fitting of the N-terminal domain of human pol $\beta$ resolved by NMR (PDB access code is 1BNP) into enzyme structure with the subsequent removing of duplicate structure part. The fitting was performed with SwissPDB Viewer software v. 4.01 [18, 23]. Missing atoms in residues Val303 were reconstructed using correct Val303 residue from another PDB entry containing data about human pol $\beta$ structure (PDB access code is $4 F 5 Q$ ). The obtained system was used as the initial structure for the further molecular dynamics (MD) computations.

All MD computations were performed with GROMACS software version 4.6.5 [20, 35] using combined CHARMM force field (CHARMM27 with implemented CMAP [27, 28]). This version of CHARMM force field is specially developed for computational investigation of heterogeneous molecular systems including proteins, nucleic acids and lipids.

The topology of 8-oxo-dGTP for application in MD simulations was performed via web-based tool SwissParam [43]. The input file for SwissParam in mol2 format was constructed from 8-oxo-dGTP atom coordinates with OpenBabel chemical converting software [34]. Electronic properties of 8-oxo-dGTP, including partial atomic charge values, were calculated via M062x density functional method [42] using a 6-31+G (d, p) basic set. The calculated values of the partial charges were used for modifying the 8-oxo-dGTP topology. Topologies of the rest components of the studied system were built via standard topology maker pdb2gmx of GROMACS software.

To simulate intracellular (realistic) conditions all further calculations were carried out in water solution containing $0.15 \mathrm{M} \mathrm{NaCl}$. Prepared complex was placed in a rectangular periodic box using editconf module of GROMACS software. Thereafter, the box was filled by water molecules (using genbox module), and $\mathrm{Na}^{+}$and $\mathrm{Cl}^{-}$ions were added into system (using genion module). The properties of water molecules were calculatied using standard TIP3 model [30]. The complete system contained 82308 atoms.

Geometry optimization for the investigated system was performed by minimizing the potential energy via the L-BFGS algorithm [12 ] with mdrun - the main module of GROMACS software [20]. The maximum number of optimization steps was 1000 . Convergence criteria were adopted by setting the maximum force on the atoms emtol $=10 \mathrm{~kJ}$ $\mathrm{mol}^{-1} \times \mathrm{nm}^{-1}$ and the maximum step size of $0.01 \mathrm{~nm}$.

For the optimized system, we performed the calculation of the position restrained molecular dynamics within 100 ps interval (to achieve the equilibrate state) and unrestrained (productive) MD within $100 \mathrm{~ns}$ time interval at $300 \mathrm{~K}$. The initial velocities were generated according to the Maxwell-Boltzmann distribution at $300 \mathrm{~K}$. The classical leap-frog algorithm was applied for the integration of the motion equations [19]; electrostatic interactions were calculated using the particle mesh Ewald method [11]; Van der Waals interactions were accounted using cut-off radius method. The temperature and pressure of the system were controlled by V-rescale thermostat [7] and Parinello-Rahman barostat, respectively. The messages about error or unacceptable steric parameters in the systems during the calculation procedures were absent.

ISSN 1996-4536 (print) • ISSN 2311-0783 (on-line) • Біологічні Студії / Studia Biologica • 2014 • Том 8/№1 • C. 29-44 
For the further quantification of the binding energy, the molecular dynamics of 8-oxo-dGTP in the solvated state was calculated. The procedure for the MD calculation of solvated 8-oxo-dGTP was the same as for the calculation of the "DNA pol $\beta$ : 8-oxodGTP : DNA" complexes, except for the periodic box size.

Fluctuations of 8-oxo-dGTP structure in free and bound states were evaluated using the rho method [29] with g_rms, g_msd and g_rmsf modules of the GROMACS software. All energy parameters of the investigated system and its components were calculated with g_energy module. The conformational energy of 8-oxo-dGTP were evaluated as the sum of intra-ligand (between atoms in 8-oxo-dGTP composition) and extra-ligand (between atoms of 8-oxo-dGTP and molecular environment) unbound contributions to the potential energy. The dynamics of hydrogen bonds was calculated using the g_hbond module. Entropic parameters were computed using quasiharmonic $(\mathrm{QH})$ approximation $[36,40]$ with modules g_covar (co-variation analysis tool) and g_anaeig (eigenvectors analysis tool).

Visualization of the structural data and analysis of geometrical parameters were performed using the Accelrys DS Vizualiser software (versions 2.0 and 3.5) (www.accelrys.com).

\section{RESULTS AND DISCUSSION}

The principle phenomenon revealed during molecular dynamics investigation is existence of two cardinally different model of behavior enzyme space, inherent to 8-oxodGTP molecule. In two cases the ligand molecule loses the connections with template $\mathrm{dA}$ and starts to migrate inside of enzyme space (trajectories 1 and 2, migrate trajectories). In the other two cases ligands (8-oxo-dGTP) stably stays in DNA polymerase active site, "keeps in touch" with template nucleotide and maintains the hydrogen bonds with it (trajectories 3 and 4, stable trajectories).

The general view of DNA pol $\beta$ :8-oxo-dGTP:DNA complex is shown on Fig. 2. Microenvironment of the 8-oxo-dGTP bound into human pol $\beta$ active site molecule consists of amino acid residues Gly179, Ser180, Arg183, Ser188, Gly189, Asp190, Asp192, Tyr271, Phe272, Gly274, Ser275, Asp276, Asn279 and nucleotide residues dA6 in template strand and dC10 in growing strand (Fig. 3). Ligand forms a number of hydrogen bonds, in particular with side chains of amino acid residues Gly179, Arg183, Gly189, Asn279, and with template nucleotide residue dA6.

Analysis of space structure evolution of 8-oxo-dGTP over the time (Fig. 4) and its intrinsic atom fluctuation (Fig. 5) testifies that spatial structure of 8-oxo-dGTP in stable trajectories appears to be sufficiently rigid despite the presence of number of bonds around which the free rotation is possible. Accordantly to obtained data, only $\mathrm{O} 6$ oxygen atom exhibits some measureable fluctuations $(0.6 \AA \hat{)})$. Ligand is fixed in active site whereas the polymerase is still in closed conformation. The average value of RMSD is $0.8 \AA$ and $1.2 \AA$ for trajectories 3 and 4 respectively, sharp increases/decreases of RMSD value aren't observed.

Obviously, that composition of ligand microenvironment practically doesn't change over the studied molecular dynamics interval in two stable trajectories. In addition to above mentioned residues of pol $\beta$ active site the 8-oxo-dGTP can interact with amino acids Arg149 and Lys280. In both cases the 8-oxo-dGTP forms time-stable network of hydrogen bonds including on the average $7 \mathrm{H}$-bonds with protein and $2 \mathrm{H}$-bonds with template DNA (Fig. 6).

ISSN 1996-4536 (print) • ISSN 2311-0783 (on-line) • Біологічні Студії / Studia Biologica • 2014 • Том 8/№1 • С. 29-44 

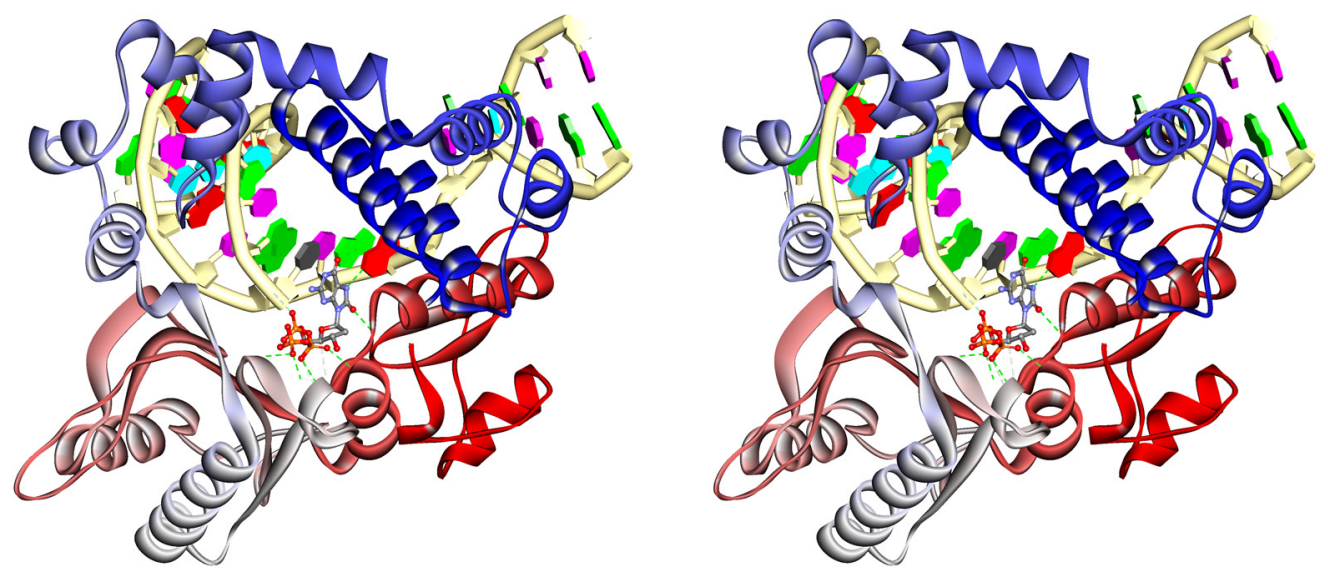

Fig. 2. General stereo view of DNA pol $\beta$ :8-oxo-dGTP:DNA complex. Protein and DNA are shown using standard ribbon diagrams. Bases in DNA are rendered by rings. 8-oxo-dGTP is shown using ball-stick (skeleton) representation (in center of view). Hydrogen bonds' network of 8-oxo-dGTP is shown by dashed lines

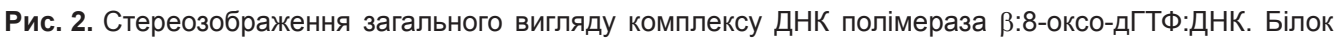
і ДНК представлені стандартними стрічковими діаграмами. Основи в ДНК зображені кільцями. 8-оксо-дГТФ показаний кулько-стрижневою (скелетною) діаграмою (в центрі зображення). Мережа водневих зв'язків 8-оксо-дГТФ представлена пунктирними лініями

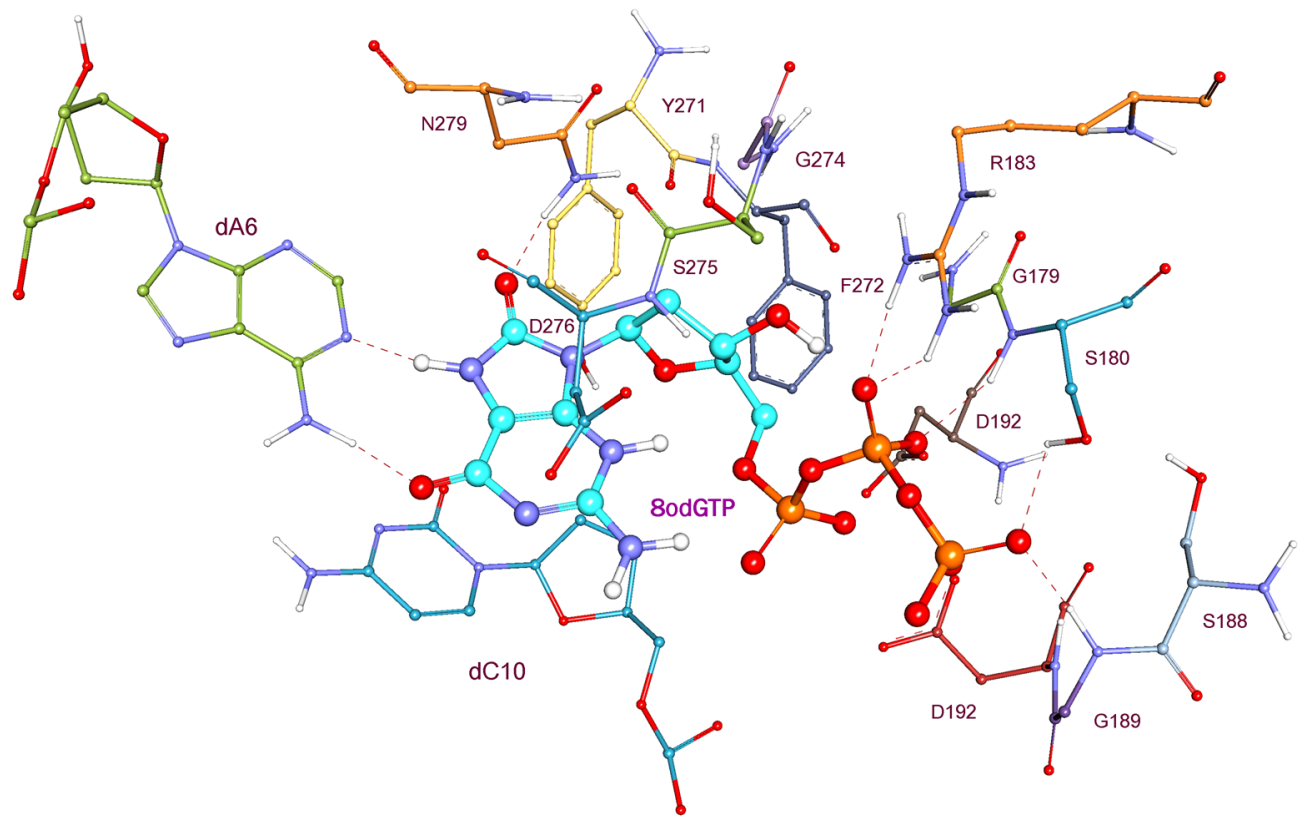

Fig. 3. Detailed organization of pol $\beta$ active site with incoming 8-oxo-dGTP molecule. Aliphatic hydrogens are not present

Рис. 3. Детальна організація активного сайта ДНК полімерази $\beta$, що містить молекулу 8-оксо-дГТФ. Аліфатичні водні не представлені 


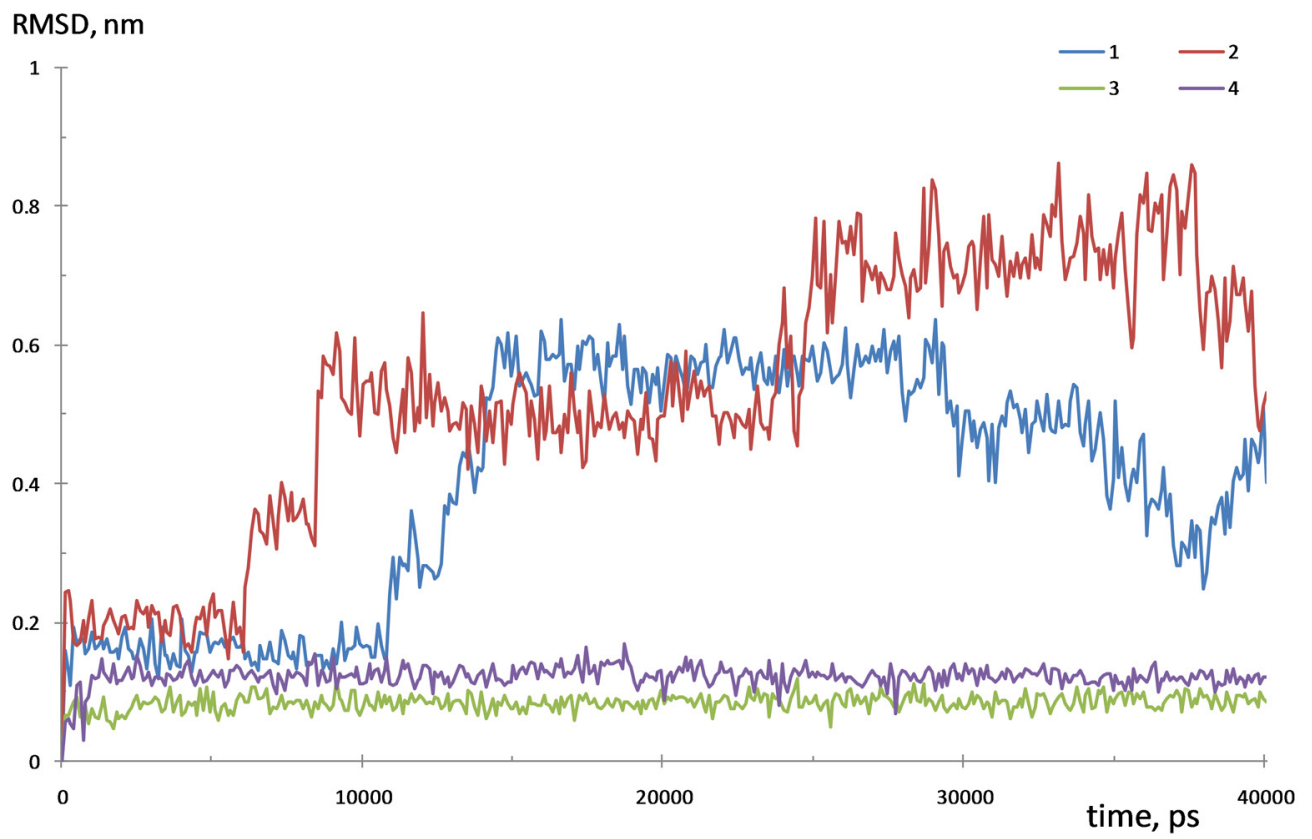

Fig. 4. Evolution of structural properties of 8-oxo-dGTP over the time of $40 \mathrm{~ns}$ molecular dynamics in different trajectories

Рис. 4. Еволюція властивостей структури 8-оксо-дГТФ у різних траєкторіях упродовж 40 нс молекулярної динаміки

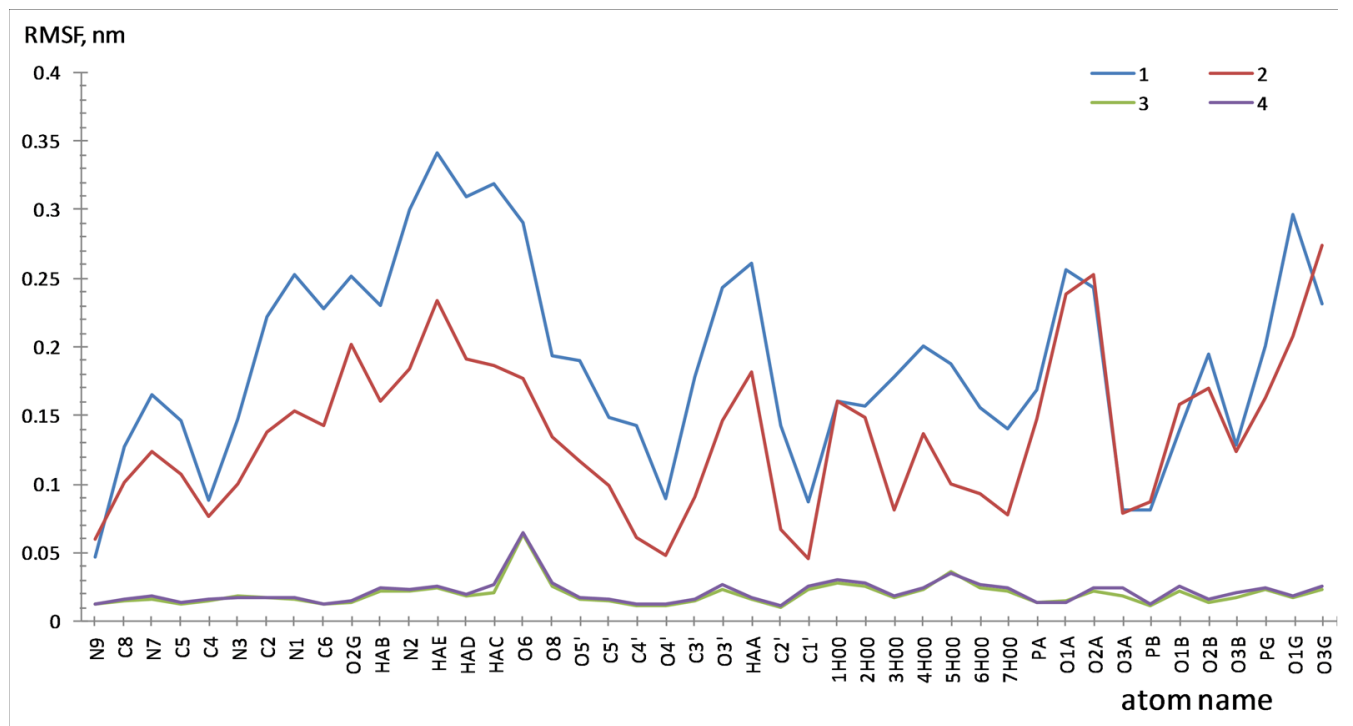

Fig. 5. Fluctuations of individual atoms in 8-oxo-dGTP composition as result of $40 \mathrm{~ns}$ molecular dynamics Рис. 5. Флуктуації індивідуальних атомів у складі 8-оксо-дГТФ унаслідок 40 нс молекулярної динаміки 


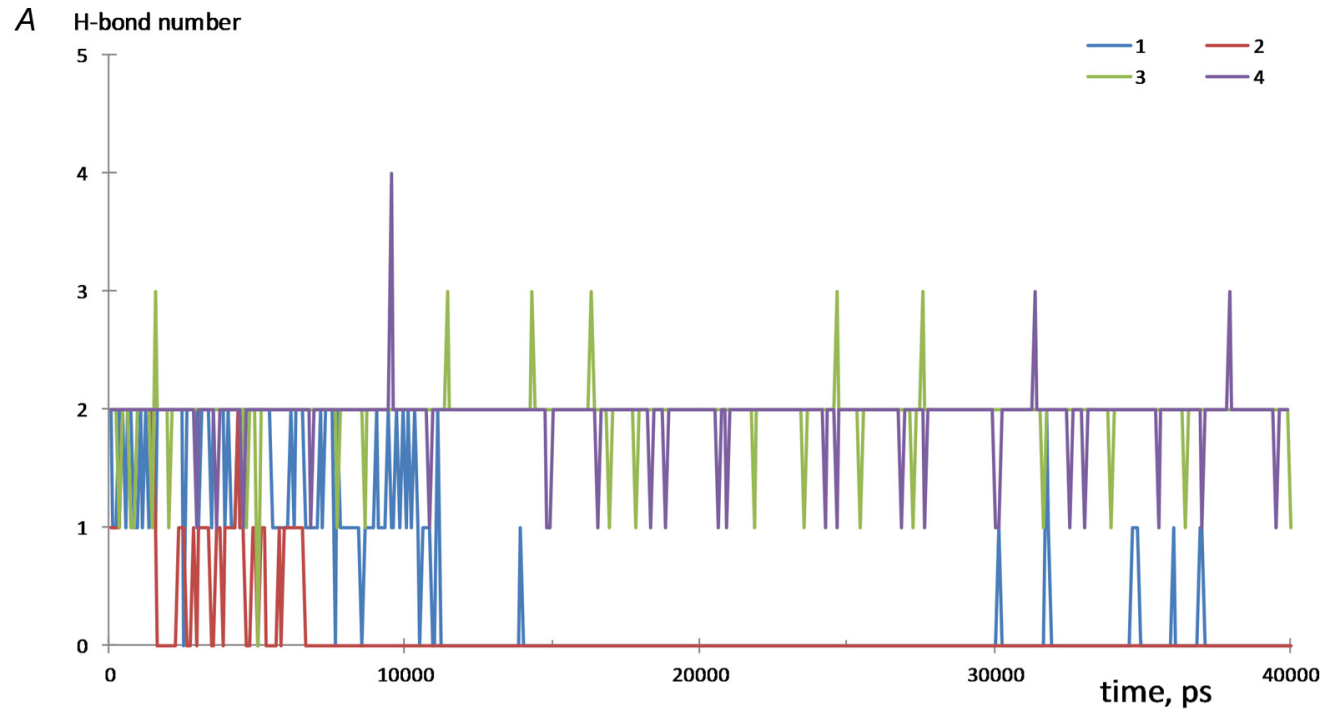

B H-bond number

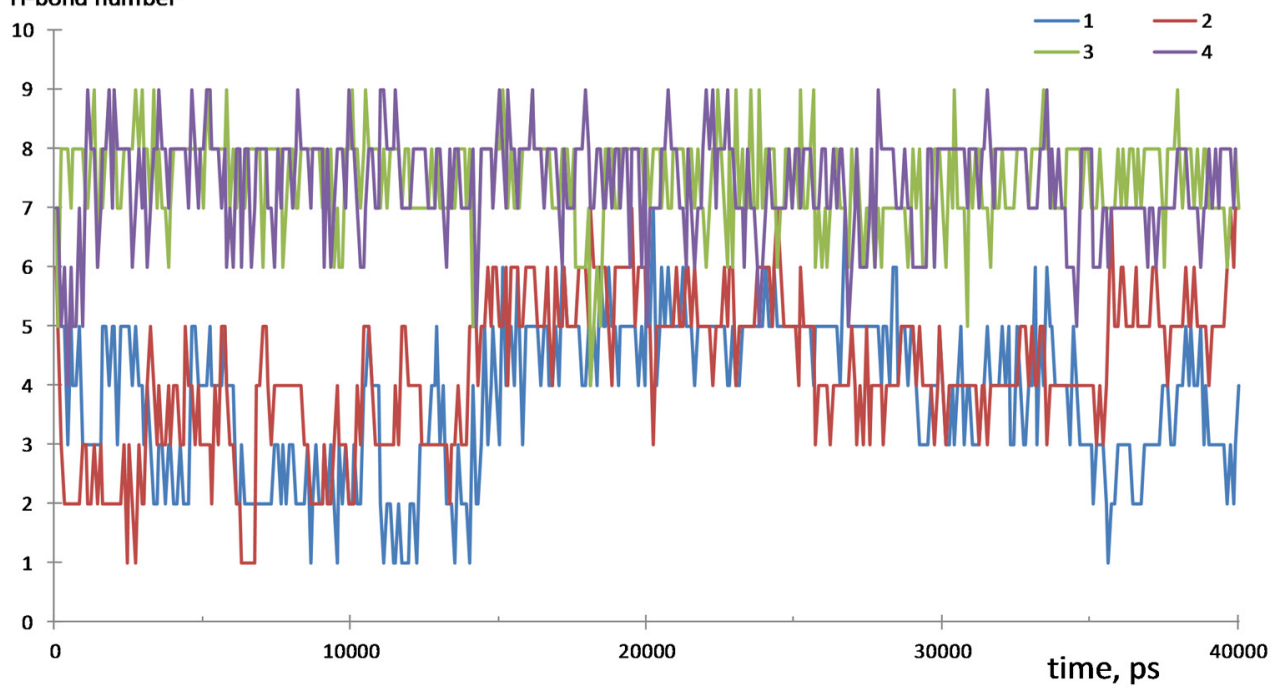

Fig 6. Alteration in hydrogen bond number over the time of 40 ns molecular dynamics: $A-$ number of $\mathrm{H}-$ bonds between 8-oxo-dGTP and DNA; $B$ - number of H-bonds between 8-oxo-dGTP and protein

Рис. 6. Зміна кількості водневих зв'язків упродовж 40 нс молекулярної динаміки: $A$ - кількість водневих зв'язків між 8-оксо-дГТФ і ДНК; $B$ - кількість водневих зв'язків між 8-оксо-дГТФ і білком

The conformational energy of ligand in both "fixed" trajectories is also characterized by high stability over the time of studied molecular dynamics. Average values of energy $(-10229.7$ and $-10227.1 \mathrm{~kJ} / \mathrm{mol})$ are practically the same for both cases. Appropriate value of conformational energy in water solution is $-6700.7 \mathrm{~kJ} / \mathrm{mol}$. No tendencies to rise or decrease of general conformational energy level are observed for investigated MD interval. 
Thus, revealed stable variants of 8-oxo-dGTP behavior evidently correspond to case of the further incorporation modified 8-oxo-dG into growing DNA strand. Obtained results about structure and energy fluctuations in stable trajectories testify that system achieves equilibrium state and can be in this state for an indefinite time (in reality - up to chemical reactions leading to addition of nucleotide to newly synthesized DNA [4, 21]).

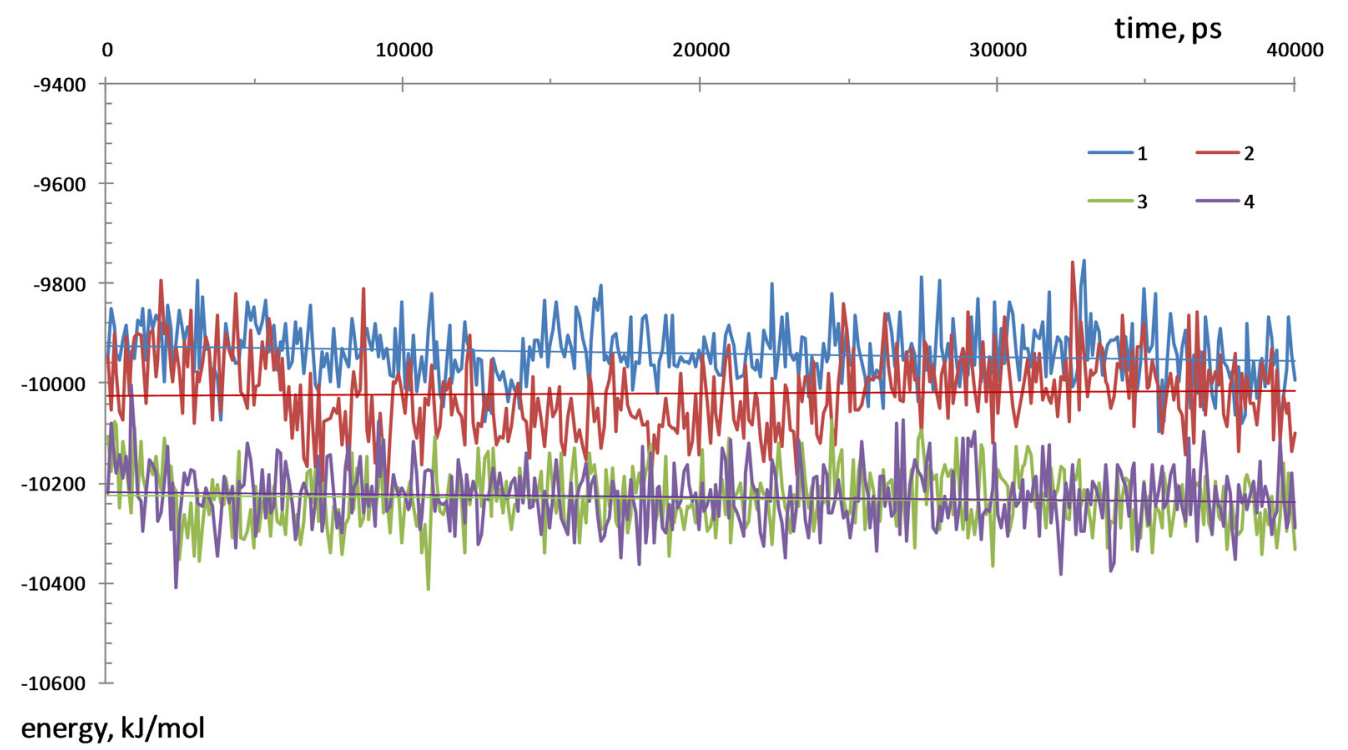

Fig. 7. Fluctuations of 8-oxo-dGTP conformational energy during $40 \mathrm{~ns}$ molecular dynamics in different trajectories. Corresponding trend lines are also present

Рис. 7. Флуктуації конформаційної енергії 8-оксо-дГТФ у різних траєкторіях упродовж 40 нс молекулярної динаміки. Також наведені відповідні лінії тренду

The behavior of 8-oxo-dGTP molecule in the rest of cases is significantly more complicated. In the first case the 8-oxo-dGTP loses the $\mathrm{H}$-bonds with template dA6 residue near at $11 \mathrm{~ns}$ of molecular dynamics (Fig. 6A) and starts to migrate in space on DNA polymerase. This event is reflected in essential rise of appropriate RMSD values during 11-15 ns of molecular dynamics (Fig. 4). Hydrogen bonds between ligand and DNA episodically appear at 30, 31, 34, 36 and 37 ns of investigated molecular dynamics (Fig. 6A).

In the second case the interaction between 8-oxo-dGTP and template adenine breaks even more early - appropriate H-bonds completely disappear at $6.5 \mathrm{~ns}$ of molecular dynamics and don't arise again (Fig. 6A). The disruption of 8-oxo-dGTP:dA6 hydrogen bonds accompanies by rising of ligand RMSD in interval of 6.5-10 MD ns that testifies about start of intra-protein migration of 8-oxo-dGTP molecule (Fig. 4). The ligand movements in the both "migratory" cases have the relatively stable periods from 15 to $30 \mathrm{~ns}$ in the first case and from $9 \mathrm{~ns} 25 \mathrm{~ns}$ in the second case. Average values of RMSD are 6.3 and $8.3 \AA$ for the first and second trajectory respectively that is essentially more than corresponded values for stable trajectories.

The 8-oxo-dGTP in movable trajectories regularly exhibits much more flexibility in comparison to itself behavior in stable trajectories that reflects in corresponded values

ISSN 1996-4536 (print) • ISSN 2311-0783 (on-line) • Біологічні Студії / Studia Biologica • 2014 • Том 8/№1 • С. 29-44 
of individual atomic fluctuations (Fig. 5). The minimal values of RMSF are proper for nitrogen $\mathrm{N} 9$ atom in the base and oxygen $\mathrm{O}^{\prime}$ atom in sugar composition.

One should mention that any changes in 8-oxo-dGTP spatial structure and $\mathrm{H}$-bond number don't influence on level and fluctuation of conformational energy (Fig. 7). Contrary to the expectations the general levels of conformational energy of 8-oxo-dGTP as well as energy fluctuation patterns in both migratory trajectories are completely time stable! The average values of conformational energy are -9938.6 and $-10018.6 \mathrm{~kJ} / \mathrm{mol}$ for trajectories 1 and 2 respectively that is slightly more than corresponded values stable for trajectories and essentially less than average conformational energy in water solution. Thus, 8-oxo-dGTP outcome from enzyme space is energetically unfavorable in all the considered cases. This phenomenon seems to be very significant since confirms our assumption that consequences of 8-oxo-dGTP discrimination from pol $\beta$ active site are essentially more complicated than simple removing of ligand from enzyme.

Hydrogen bond dynamics character for 8-oxo-dGTP in migratory trajectories are different from stable trajectory ones. The number of $\mathrm{H}$-bonds between ligand and protein is floating from 1 to 7 with average value 4 over the complete trajectory (Fig. 6B) that is well agree with complicated pattern of intra-protein movement of 8-oxo-dGTP molecule.

Accordantly to data of trajectory visual analysis, the 8-oxo-dGTP doesn't reveal tendency to leave the DNA polymerase space. Conformational space occupied by 8-oxo-dGTP is more compact in trajectory 1 than in trajectory (Fig. 7). The 8-oxo-dGTP movement pathway of don't coincide each other that is confirmed by differences of amino acid microenvironment of ligand in the same time points (Table).

\section{Amino acid compositions of 8-oxo-dGTP microenvironmemt at several points of molecular dynamics}

\section{Амінокислотні композиції 3 мікрооточення 8-оксо-ДГТФ} у декількох точках молекулярної динаміки

\begin{tabular}{|c|c|c|}
\hline Time point, ns & Trajectory 1 & Trajectory 2 \\
\hline 10 & $\begin{array}{l}\text { Arg149, Gly179, Ser180, Arg183, } \\
\text { Tyr271, Phe272, Thr273, Gly274, } \\
\text { Ser275, Asn279 }\end{array}$ & $\begin{array}{l}\text { Thr10, Leu11, Ala47, Lys48, Tyr49, } \\
\text { Pro50, Arg149, Glu186, Ser187 }\end{array}$ \\
\hline 20 & $\begin{array}{l}\text { Arg149, Cys178, Gly179, Ser180, } \\
\text { Arg183, Asp192,Tyr271, Phe272, } \\
\text { Thr273, Gly274, Ser275, Asp276 }\end{array}$ & $\begin{array}{c}\text { Thr10, Ala47, Lys48, Pro50, Arg149, } \\
\text { Ser187, Ser334, Glu335 }\end{array}$ \\
\hline 30 & $\begin{array}{c}\text { Arg40, Arg149, Arg183, } \\
\text { Asp192,Tyr271, Phe272, Gly274, } \\
\text { Ser275, Asp276 }\end{array}$ & $\begin{array}{c}\text { Thr10, Ala47, Lys48, Tyr49, Arg149, } \\
\text { Ser334 }\end{array}$ \\
\hline 40 & $\begin{array}{l}\text { Lys27, Arg40, Arg149, Asp276, } \\
\text { Ile277, Lys280 }\end{array}$ & $\begin{array}{c}\text { Thr10, Leu11, Ile46, Ala47, Lys48, } \\
\text { Tyr49, Pro50, Arg149 }\end{array}$ \\
\hline
\end{tabular}

It seems to be the most important that 8-oxo-dGTP not only does not leave the enzyme space but directly prevent transition of DNA polymerase from closed to open conformation as well as the further binding of incoming dNTP. This observation lets a possibility to consider it as natural inhibitor of DNA pol $\beta$ activity.

ISSN 1996-4536 (print) • ISSN 2311-0783 (on-line) • Біологічні Студії / Studia Biologica • 2014 • Том 8/№1 • C. 29-44 

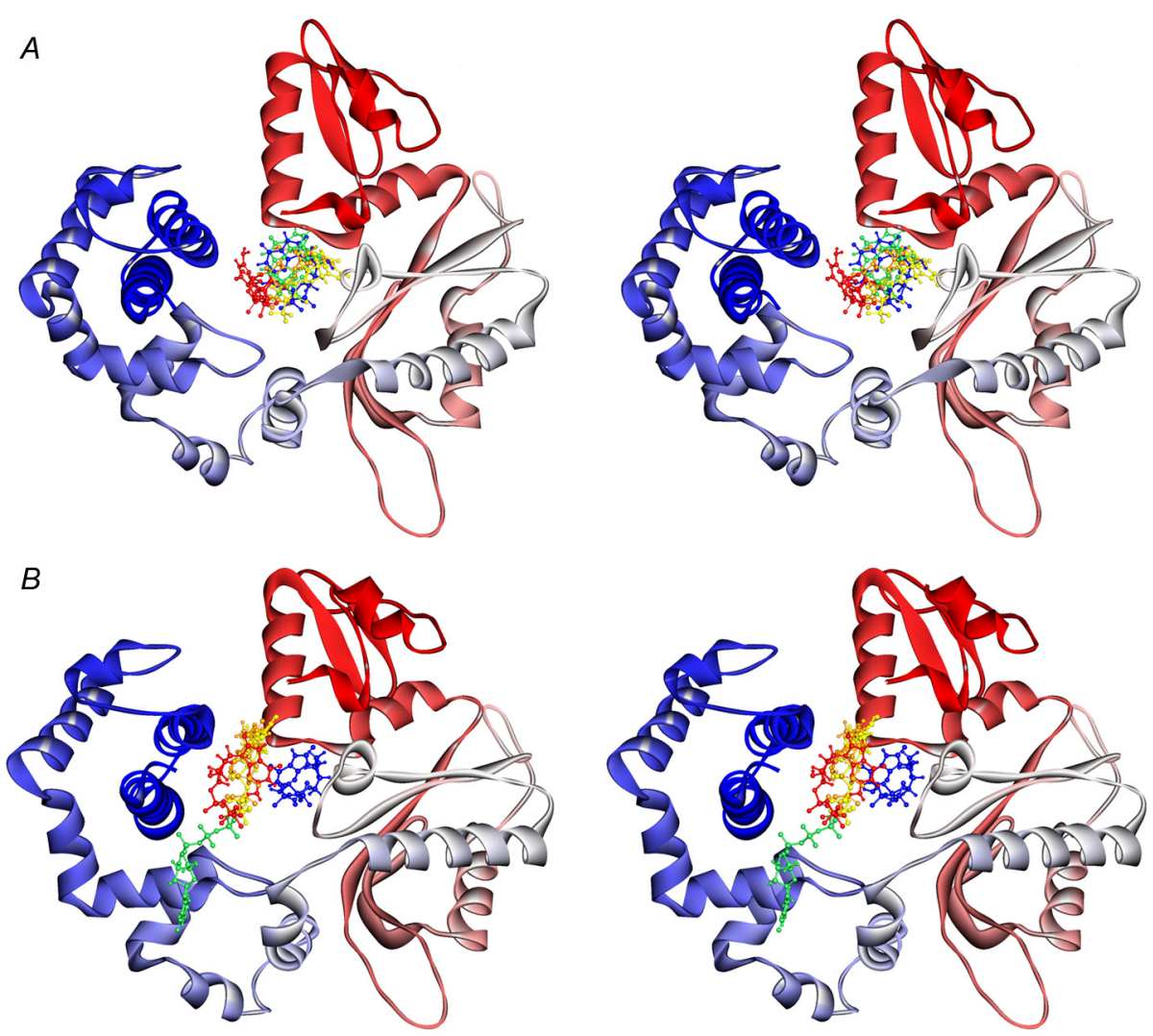

Fig. 8. Some key poses of 8-ox-dGTP in DNA pol $\beta$ space during molecular dynamics $(A-$ trajectory $1 ; B-$ trajectory 2). Poses at 0,10, 20, 30 and 40 ns colored by blue, green, yellow, orange and red respectively. DNA molecules aren't present

Рис. 8. Деякі ключові геометрії 8-оксо-дГТФ у просторі ДНК полімерази $\beta$ впродовж молекулярної динаміки ( $A$ - траєкторія 1 ; $B$-траєкторія 2). Геометрії на 0, 10, 20, 30 і 40 наносекунді забарвлені відповідно синім, зеленим, жовтим, жовтогарячим і червоним кольорами. Молекули ДНК не представлені

\section{SUMMARY}

Two different ways of 8-oxo-dGTP behavior discovered during present investigations well agree with our conceptions about two possible events that are results of its binding in active site of DNA polymerase $\beta$. The firstly described by us migratory way of behavior of modified nucleotide triphosphate in enzyme space appears to be functionally significant.

In context of accumulative data, the 8-oxo-dGTP seems to be not only genome instability factor but natural inhibitor of DNA pols $\beta$ with rather unusual way of interaction with target enzyme. The ability of 8-oxo-dGTP molecule to remain in DNA pol $\beta$ space over essential time intervals (without dissociation) and, thus, inhibit its catalytic activity can turn out a very important to maintain homeostasis at cellular and tissue level. It's known that malignantly transformed cells are exceptionally abundant in reactive oxygen species and thus, a priori maintain a high level of oxidized base in both DNA and DNA 
precursors [14, 17]. Moreover, rapid increase of ROS concentration in cell can be one of the first sign of its starting (incipient) neoplastic transformation [14, 17].

Taking into account the especial role of ROS in carcinogenesis, the 8-oxo-dGTP might be supposed as (one of) possible natural regulator which mediates the direct transition of the cell from normal state to programmed cell death omitting the malignancy stage. We can assume the next outline of intracellular events. The oxidative stress causes a rapid increase of intracellular concentration of oxidized nucleotides, including 8-oxo-dGTP. High concentration of 8-oxo-dGTP inhibits the activity of main reparative DNA polymerase $\beta$ and results in numerous DNA damages incompatible with life. Proposed regulative mechanism seems to be sufficiently logical, but demand the further experimental verification.

The discovered phenomenon of delayed dissociation of heterogenic protein:ligand: DNA complexes potentially can extend our conceptions about structural mechanisms of specific recognition and interaction between different types of biomolecules.

1. Batra V.K., Beard W.A., Hou E.W. et al. Mutagenic conformation of 8-oxo-7,8-dihydro-2'dGTP in the confines of a DNA polymerase active site. Nat. Struct. Mol. Biol, 2010; 17(7): 889-890.

2. Batra V.K., Shock D.D., Beard W.A. et al. Binary complex crystal structure of DNA polymerase $\beta$ reveals multiple conformations of the templating 8-oxoguanine lesion. Proc. Natl. Acad. Sci. USA, 2012; 109(1): 113-118.

3. Beard W.A., Batra V.K., Wilson S.H. DNA polymerase structure-based insight on the mutagenic properties of 8-oxoguanine. Mutat Res, 2010; 703(1): 18-23.

4. Berdis A. J. Mechanisms of DNA polymerases. Chem. Rev, 2009; 109(7): 2862-2879.

5. Berman H.M., Westbrook J., Feng Z. et al. The Protein Data Bank. Nucleic Acids Res, 2000; 28: 235-242.

6. Brown J.A., Duym W.W., Fowler J.D., Suo Z. Single-turnover kinetic analysis of the mutagenic potential of 8-oxo-7,8-dihydro-2'-deoxyguanosine during gap-filling synthesis catalyzed by human DNA polymerases $\lambda$ and $\beta$. J. Mol. Biol, 2007; 367: 1258-1269.

7. Bussi G., Donadio D., Parrinello M. Canonical sampling through velocity rescaling. J. Chem. Phys, 2007; 126: 014101.

8. Cadet J., Wagner J.R. DNA base damage by reactive oxygen species, oxidizing agents, and UV radiation. Cold Spring Harb. Perspect. Biol, 2013; 5(2): pii a012559.

9. Cadet J., Douki T., Gasparutto D., Ravanat J.L. Oxidative damage to DNA: formation, measurement and biochemical features. Mutat. Res, 2003; 531(1-2): 5-23.

10. Chen V.B., Arendall W.B. 3rd, Headd J.J. et al. MolProbity: all-atom structure validation for macromolecular crystallography. Acta Crystallogr. D. Biol. Crystallogr, 2010; 66(Pt 1): 12-21.

11. Darden T., York D., Pedersen L. Particle mesh Ewald: An Nlog(N) method for Ewald sums in large systems. J. Chem. Phys, 1993; 98: 10089-10092.

12. Das B., Meirovitch H., Navon I.M. Performance of hybrid methods for large-scale unconstrained optimization as applied to models of proteins. J. Comput. Chem, 2003; 24: 1222-12231.

13. Davis I.W., Leaver-Fay A., Chen V.B. et al. MolProbity: all-atom contacts and structure validation for proteins and nucleic acids. Nucleic Acids Res, 2007; 35 (Web Server issue): W375-383.

14. Dizdaroglu M. Oxidatively induced DNA damage: mechanisms, repair and disease. Cancer Lett, 2012; 327(1-2): 26-47.

15. Einolf H.J., Guengerich F.P. Fidelity of nucleotide insertion at 8-oxo-7,8-dihydroguanine by mammalian DNA polymerase delta. Steady-state and pre-steady-state kinetic analysis. J. Biol. Chem, 2001; 276: 2763764-3771.

16. Eoff R.L., Irimia A., Angel K.C. et al. Hydrogen bonding of 7,8-dihydro-8-oxodeoxyguanosine with a charged residue in the little finger domain determines miscoding events in Sulfolobus solfataricus DNA polymerase Dpo4. J. Biol. Chem, 2007; 282(27): 19831-19843.

ISSN 1996-4536 (print) • ISSN 2311-0783 (on-line) • Біологічні Студії / Studia Biologica • 2014 • Том 8/№1 • C. 29-44 
17. Feig D.I., Reid T.M., Loeb L.A. Reactive oxygen species in tumorigenesis, Cancer Res, 1994; 541890s-1894s.

18. Guex N., Peitsch M.C. SWISS-MODEL and the Swiss-PdbViewer: An environment for comparative protein modeling. Electrophoresis, 1997; 18: 2714-2723.

19. Hockney R. W., Goel S. P., Eastwood J. Quiet High resolution computer models of a plasma. J. Comp. Phys, 1974; 14: 148-158.

20. Hess B., Kutzner C., van der Spoel D., Lindhal E. GROMACS 4: algorithms for highly efficient, load-balanced, and scalable molecular simulation. Chem. Theory Comput, 2008; 4: 435-447.

21. Hübscher U., Spadari S., Villani G., Maga G. DNA Polymerases: Discovery, characterization and functions in cellular DNA transactions. World Scientific, New Jersey, 2010.

22. Jena N. R. DNA damage by reactive species: Mechanisms, mutation and repair. J. Biosci, 2012; 37(3): 503-517.

23. Johansson M.U., Zoete V., Michielin O., Guex N. Defining and searching for structural motifs using DeepView/Swiss-PdbViewer. BMC Bioinformatics, 2012; 13: 173

24. Katafuchi A., Nohmi T. DNA polymerases involved in the incorporation of oxidized nucleotides into DNA: their efficiency and template base preference. Mutat Res, 2010; 703(1): 24-23.

25. Katafuchi A., Sassa A., Niimi N. et al. Critical amino acids in human DNA polymerases $\eta$ and $\mathrm{K}$ involved in erroneous incorporation of oxidized nucleotides. Nucleic Acids Res, 2010; 38 : 859-867.

26. Kunkel T. A. DNA replication fidelity. J. Biol. Chem, 2004; 279(17): 16895-16898

27. MacKerell A.D Jr., Banavali N., Foloppe N. Development and current status of the CHARMM force field for nucleic acids. Biopolymers, 2000-2001; 56(4): 257-265.

28. Mackerell A.D. Jr., Feig M., Brooks C.L. 3rd. Extending the treatment of backbone energetics in protein force fields: limitations of gas-phase quantum mechanics in reproducing protein conformational distributions in molecular dynamics simulations. J. Comput. Chem, 2004; 25(11): 1400-1415.

29. Maiorov V. N., Crippen G.M. Size-independent comparison of protein three-dimensional structures. Proteins, 1995; 22: 273-283

30. Mahoney M.W., Jorgensen W.L. A five-site model for liquid water and the reproduction of the density anomaly by rigid, non-polarizable potential functions. J. Chem. Phys, 2000; 112: 8910-8922.

31. Markkanen E., Hübscher U., van Loon B. Regulation of oxidative DNA damage repair: the adenine:8-oxo-guanine problem. Cell Cycle, 2012; 11(6): 1070-1075.

32. Miller H., Prasad R., Wilson S.H. et al. 8-oxodGTP incorporation by DNA polymerase $\beta$ is modified by active-site residue Asn279. Biochemistry, 2000; 39: 1029-1033.

33. Nakabeppu Y., Sakumi K., Sakamoto K. et al. Mutagenesis and carcinogenesis caused by the oxidation of nucleic acids. Biol. Chem, 2006; 387(4): 373-379.

34. O'Boyle N.M., Banck M., James C.A. et al. Open Babel: An open chemical toolbox. J. Cheminform, 2011; 3: 33

35. Pronk S., Páll S., Schulz R. et al. GROMACS 4.5: a high-throughput and highly parallel open source molecular simulation toolkit. Bioinformatics, 2013; 29(7): 845-854.

36. Schlitter J. Estimation of absolute and relative entropies of macromolecules using the covariance matrix. Chem. Phys. Letters, 1993; 215(6): 617-621.

37. Shimizu M., Gruz P., Kamiya H., Kim S.R., Pisani F.M., Masutani C., Kanke Y., Harashima H., Hanaoka F., Nohmi T. Erroneous incorporation of oxidized DNA precursors by Y-family DNA polymerases. EMBO Rep, 2003; 4: 269-273.

38. Shimizu M., Gruz P., Kamiya H. et al. Efficient and erroneous incorporation of oxidized DNA precursors by human DNA polymerase $\eta$. Biochemistry, 2007; 46: 5515-5522.

39. Van der Spoel D., Lindahl E., Hess B. et al. GROMACS: fast, flexible, and free. J. Comput. Chem, 2005; 26: 1701-1718.

40. Wang J., Bruschweiler R. J. Chem. Theory Comput, 2006; 2(1): 18-24.

41. Van Loon B., Markkanen E., Hübscher U. Oxygen as a friend and enemy: How to combat the mutational potential of 8-oxo-guanine. DNA Repair (Amst), 2010; 9(6): 604-616. 
42. Zhao Y., Truhlar D. G. The M06 suite of density functionals for main group thermochemistry, thermochemical kinetics, noncovalent interactions, excited states, and transition elements: two new functionals and systematic testing of four M06-class functionals and 12 other functional. Theor. Chem. Acc, 2008; 120: 215-241.

43. Zoete V., Cuendet M.A., Grosdidier A., Michielin O. SwissParam: a fast force field generation tool for small organic molecules. J. Comput. Chem, 2011; 32(11): 2359-2368.

\section{ОСОБЛИВОСТІ ПОВЕДІНКИ 8-ОКСО-7,8-ДИГІДРО-2'-ДГТФ В АКТИВНОМУ САЙТІ ДНК-ПОЛІМЕРАЗИ $\beta$ ЛЮДИНИ: СТРУКТУРНІ ДОСЛІДЖЕННЯ IN SILICO}

\section{О. Ю. Нипорко}

Київський національний університет імені Тараса Шевченка вул. Володимирська, 64/13, Київ 01601, Україна e-mail:dfnalex@gmail.com, anyporko@univ.net.ua

Окислені основи у складі ДНК і ДНК попередників (дезоксинуклеотид трифосфратів, дНТФ), що виникають у живій клітині в результаті окислювального стресу, $€$ одним із основних джерел нестабільності геному. Серед окислених форм азотистих основ найбільш поширеним є 8-оксо-7,8-дигідро-2-дезоксигуанін (8одГ, 8-оксоДГ). Ця сполука має високий мутагенний потенціал унаслідок здатності переважно взаємодіяти з аденіном замість цитозину. Зокрема, 8одГ у складі вхідного нуклеотиду (8-оксо-дГТФ) здатний безпосередньо включатися в ланцюг ДНК, що нарощується, i, таким чином, спричиняти заміну дА $\rightarrow$ дЦ, оскільки він здатний спарюватись як із вхідним дЦТФ, так і з дАТФ у наступному циклі реплікації ДНК.

Ефективність включення 8-оксо-дГ у зростаючу ДНК чітко залежить від природи відповідних ДНК-полімераз. Однією з найбільш чутливих до 8-оксо-дГТФ $\epsilon$ еукаріотична ДНК-полімераза $\beta$ (pol $\beta$ ). Зв'язування 8-оксо-дГТФ в активному центрі pol $\beta$ може приводити до двох різних молекулярних подій. Першою з них $€$ включення 8-оксогуаніну в ланцюг ДНК, що синтезується, другою - дискримінація 8-оксо-дГТФ з активного центру. В той час, як наслідки включення цього модифікованого гуаніну в ДНК є добре дослідженими, безпосередні результати дискримінації 8-оксо-дГТФ все ще залишаються неясними.

Поведінку молекули 8-оксо-дГТФ у ділянці активного сайту ДНК-полімерази $\beta$ людини було досліджено шляхом розрахунків молекулярної динаміки (МД). Основоположним феноменом, виявленим у результаті досліджень, $є$ існування двох кардинально відмінних моделей поведінки, властивих молекулі 8-оксо-дГТФ. У двох випадках молекула ліганда втрачає зв'язки з матричним дА і починає мігрувати всередину простору ферменту (міграційні траєкторії). У двох інших випадках 8-оксо-дГТФ стабільно залишається в активному центрі ДНК-полімерази, “залишається на зв'язку” з матричним нуклеотидом і підтримує водневі зв'язки з ним (стабільні траєкторії).

Просторова структура 8-оксо-дГТФ у стабільних траєкторіях виявляється досить жорсткою, незважаючи на цілий ряд зв'язків, навколо яких можливе вільне обертання, а його конформаційна енергія характеризується високою стабільністю протягом часу досліджуваної МД. Середні значення енергії (-10229,7 і -10227,1 кДж/ моль) практично тотожні для обох випадків. Амінокислотне мікрооточення 8-оксодГТФ також практично не змінюється протягом досліджуваного періоду М. Таким чином, стабільні варіанти поведінки 8-оксо-дГТФ, вочевидь, відповідають випадку подальшого включення модифікованого 8-оксо-дГ у ланцюг ДНК, що синтезується.

ISSN 1996-4536 (print) • ISSN 2311-0783 (on-line) • Біологічні Студії / Studia Biologica • 2014 • Том 8/№1 • C. 29-44 
Поведінка молекули 8-оксо-дГТФ у міграційних траєкторіях є суттєво складнішою. 8-оксо-дГТФ втрачає водневі зв'язки з матричним дА6 (на 11 і 6,5 нс МД в першому і другому випадку відповідно) і починає мігрувати у просторі ДНК-полімерази. Просторова структура 8-оксо-дГТФ закономірно проявляє більшу гнучкість порівняно з поведінкою у стійких траєкторіях, що відбивається у відповідних значеннях фрлуктуацій індивідуальних атомів. Проте, всупереч очікуванням, загальні рівні конформаційної енергії 8-оксо-дГТФ, а також патерни флуктуацій енергії в обох міграційних траєкторіях $є$ повністю стабільними в часі. Середні значення конформаційної енергії становлять -9938,6 і -10018,6 кДж/моль для траєкторій 1 і 2 відповідно, що лише трішки більше відповідних значень для стабільних траєкторій. Шляхи руху 8-оксо-дГТФ не збігаються один з одним, що підтверджується відмінностями їх конформаційних просторів і амінокислотного мікрооточення. Представляється найбільш важливим, що 8-оксо-дГТФ не тільки не залишає простір ферменту, але й безпосередньо перешкоджає переходу ДНК-полімерази із закритої конформації у відкриту і подальшому зв'язуванню вхідного дНТФ. Це спостереження дає можливість розглядати його як природний інгібітор ДНК полімерази $\beta$ і можливий внутрішньоклітинний регулятор, який опосередковує прямий перехід клітини від нормального стану до запрограмованої клітинної смерті, минаючи стадію злоякісного переродження.

Ключові слова: 8-оксо-7,8-дигідро-2'-дГТФ, 8-оксо-дГТФ, ДНК-полімераза $\beta$, молекулярна динаміка, структурний аналіз, затримка дисоціації.

\section{ОСОБЕННОСТИ ПОВЕДЕНИЯ 8-ОКСО-7,8-ДИГИДРО-2'-ДГТФ В АКТИВНОМ САЙТЕ ДНК-ПОЛИМЕРАЗЫ $\beta$ ЧЕЛОВЕКА: СТРУКТУРНЫЕ ИССЛЕДОВАНИЯ IN SILICO}

А. Ю. Нипорко

Киевский национальный университет имени Тараса Шевченко ул. Владимирская, 64/13, Киев, 01601, Украина e-mail:dfnalex@gmail.com, anyporko@univ.net.ua

Окисленные основания в составе ДНК и ДНК предшественников (дезоксинуклеотид трифосфатов, дНТФ), возникающие в живой клетке в результате окислительного стресса, являются одним из основных источников нестабильности генома. Среди окисленных фрорм азотистых оснований наиболее распространенным является 8-оксо-7,8-дигидро-2-дезоксигуанин (8одГ, 8-оксо-дГ). Это соединение имеет высокий мутагенный потенциал вследствие способности предпочтительно взаимодействовать с аденином вместо цитозина. В частности, 8одГ в составе входящего нуклеотида (8-оксо-дГТФ) способен непосредственно включаться в растущую цепь ДНК и, таким образом, вызвать замену дА $\rightarrow$ дЦ, поскольку он способен спариваться как с входящим дЦТФ, так и с дАТФ в следующем цикле репликации ДНК.

Эфрфективность включения 8-оксо-дГ в растущую ДНК четко зависит от природы соответствующих ДНК-полимераз. Одной из наиболее чувствительных к 8-оксодГТФ является эукариотическая ДНК-полимераза (pol $\beta)$. Связывание 8-оксо-дГТФ в активном центре pol $\beta$ может приводить к двум различным молекулярным событиям. Первым из них является включение 8-оксогуанина в растущую цепь ДНК, другим -

ISSN 1996-4536 (print) • ISSN 2311-0783 (on-line) • Біологічні Студії / Studia Biologica • 2014 • Том 8/№1 • С. 29-44 
исключение 8-оксо-дГТФ из активного центра. В то время, как следствия включения этого модифицированного гуанина в ДНК исследованы хорошо, непосредственные результаты дискриминации 8-оксо-дГТФ всё ещё остаются неясными.

Поведение молекулы 8-оксо-дГТФ в области активным сайтом ДНК-полимеразы $\beta$ человека было исследовано путём расчетов молекулярной динамики (МД). Основополагающим феноменом, выявленным в результате исследований, является существование двух кардинально отличных моделей поведения, свойственных молекуле 8-оксо-дГТФ. В двух случаях молекула лиганда теряет связи с матричным дА и начинает мигрировать внутрь пространства фрермента (миграционные траектории). В двух других случаях 8-оксо-дГТФ стабильно остается в активном центре ДНК-полимеразы, “остаётся на связи” с матричным нуклеотидом и поддерживает водородные связи с ним (стабильные траектории).

Пространственная структура 8-оксо-дГТФ в стабильных траекториях оказывается достаточно жесткой, несмотря на целый ряд связей, вокруг которых возможно свободное вращение, а его конформационная энергия характеризуется высокой стабильностью в течение времени исследуемой МД. Средние значения энергии (-10229,7 и -10227,1 кДж/моль) практически тождественны для обоих случаев. Аминокислотное микроокружение 8-оксо-дГТФ также практически не меняется в течение исследуемого периода МД. Таким образом, стабильные варианты поведения 8-оксо-дГТФ, очевидно, соответствуют случаю последующего включения модифицированного 8-оксо-дГ в растущую цепь ДНК.

Поведение молекулы 8-оксо-дГТФ в миграционных траекториях является значительно более сложным. 8-оксо-дГТФ теряет водородные связи с матричным дА6 (на 11 и 6,5 нс МД в первом и втором случае соответственно) и начинает мигрировать в пространстве ДНК-полимеразы. Пространственная структура 8-оксо-дГТФ закономерно проявляет большую гибкость по сравнению с поведением в устойчивых траекториях, что отражается в соответствующих значениях фрлуктуаций индивидуальных атомов. Тем не менее, вопреки ожиданиям, общие уровни конформационной энергии 8-оксо-дГТФ, а также паттерны флуктуаций энергии в обеих миграционных траекториях полностью стабильны во времени. Средние значения конформационной энергии составляют -9938,6 и -10018,6 кДж/моль для траекторий 1 и 2 соответственно, что лишь слегка больше соответствующих значений для стабильных траекторий. Пути движения 8-оксо-дГТФ не совпадают друг с другом, что подтверждается различиями их конформационных пространств и аминокислотного микроокружения. Представляется наиболее важным, что 8-оксо-дГТФ не только не покидает пространство фермента, но и напрямую препятствует переходу ДНКполимеразы из закрытой конформации в открытую и последующему связыванию входящего дНТФ. Это наблюдение даёт возможность рассматривать его как естественный ингибитор ДНК полимеразы $\beta$ и возможный внутриклеточный регулятор, который опосредует прямой переход клетки от нормального состояния к запрограммированной клеточной смерти, минуя стадию злокачественного перерождения.

Ключевые слова: 8-оксо-7,8-дигидро-2'-дГТФ, 8-оксо-дГТФ, ДНК-полимераза $\beta$, молекулярная динамика, структурный анализ, задержка диссоциации.

Одержано: 03.02.2014

ISSN 1996-4536 (print) • ISSN 2311-0783 (on-line) • Біологічні Студії / Studia Biologica • 2014 • Том 8/№1 • С. 29-44 